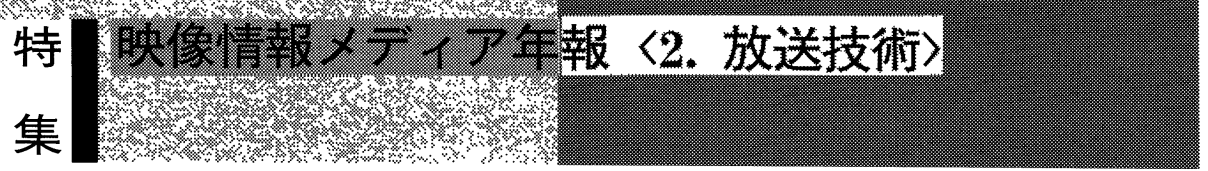

\title{
2-3 無線・光伝送
}

\section{1.,4., 7. 伊 藤 公 ${ }^{\dagger 1}$ (正会員)，2. 福岡 宜 重 $^{\dagger 2}$ (正会員) 3. 佐藤 亨 ${ }^{\dagger 3}$ (正会員)，5. 村上 泰 典 $^{\dagger 4}$ (正会員)，6. 前田幹 夫 $^{\dagger 5}$ (正会員)}

\section{1. ま え がき}

近年, 各国において地上ディジタル テレビジョン放送の実用化が急速に進 められており，それに関連する送受信 技術のディジタル化が重要な課題とな っている。また，マルチメディアやイ ンターネットサービス等を含む情報化 社会の発展に伴い, 通信および放送サ ービスの融合が始まっている.さら に，携帯電話やカーナビゲーションシ ステム等に代表される移動送受信の普 及には目を見張るものがある。

無線・光伝送技術はこれらの重要な 基盤技術のひとつであり，本章におい てその動向を振り返ってみる。2. で は，テレビ放送および中波放送のディ ジタル送信技術に関する最近の話題を 紹介し, さらに地上ディジタルテレビ ジョン放送の伝送技術について述べ る. 3.では，まず地上における素材 伝送技術として，800 MHz 帯，マイ クロ波帯およびミリ波帯のディジタル FPU(Field Pick-up Unit)について紹 介する。次に, 衛星を利用した素材伝 送技術であるディジタル SNG（Satellite News Gathering) について触れ

$\dagger 1$ 千葉大学 工学部

†2 株式会社東芝 流通・放送・金融システム事 業部

†3 日本電気株式会社 放送映像事業部

$\dagger 4$ 住友電気工業株式会社 オプトエレクトロニ クス研究所

†5 NHK 放送技術研究所

“2-3 Radio and Optical Fiber Transmission" by Koichi Ito (Chiba University, Chiba), Shigenobu Fukuoka (Toshiba Corporation, Kawasaki), Tohru Sato (NEC Co., Ltd., Kawasaki), Yasunori Murakami (Sumitomo Electric Industries, Ltd., Yokohama) and Mikio Maeda (NHK Science and Technical Research Laboratorries, Tokyo)
る.4.では，テレビ受信用および移 動体通信用アンテナに関する最近のト ピックスを紹介する。続いて電波伝搬 および電磁環境に関する動向をまと め, さらに, 電磁界解析について簡単 に述べる. 5. では, ケーブルテレビ 伝送技術に関連した話題として，通信 および放送サービスの融合，ディジタ ル伝送技術および伝送装置を紹介す る. 6.では, 放送素材伝送および放 送分配という観点から, 最近の光伝送 技術に関する話題をまとめる. 最後 に, 7.として, 将来動向を展望する.

(伊藤)

\section{2. 送信・受信技術}

\section{1 送信技術}

スタジオ設備から始まったディジタ ル化の進展は, 送信技術にも拡大して きた。

\section{（1）テレビ送信機}

テレビ送信機の歪み補償回路がディ ジタル化された1)。送信機で発生する 非線形歪み・線形歪みを測定し，この 信号と理想信号を比較し, 送信機の歪 みがなくなる補償量を計算する。結果 をディジタル補償回路で補償すること により，送信機の歪みを自動で補償す る。これにより高精度な補償を実現し ている。

送信機の監視機能の高機能化が図ら れているのが最近の傾向である. 従来 は, 監視項目は LED・メータにより 表示していたが, ELディスプレイ上 にグラフィカルに表示する装置が開発 された ${ }^{2) 31}$.この装置にはロガー機能 もあり, 電力増幅器の電流電圧值等の アナログ項目，あるいは，異常内容を
示すディジタル項目の収集および蓄積 が可能である。また，デー夕の収集お よび蓄積には専用の装置として産業用 のパソコンを用いたものが新たに開発 されている4).

テレビ中継放送所の雷害防止対策と して, 光ファイバで送受信部を電気的 に分離するとともに，ニオブ酸リチウ 厶 $\left(\mathrm{LiNbO}_{3}\right)$ 変調器の変調感度の改善 を図ることにより，テレビ電波受信部 に電源の不要な光伝送システムが開発 され, NHK 福岡・㛜原テレビ中継放 送所および河合テレビ中継放送所に導 入された5)。このシステムでは，3本 のシングルモード光ファイバのうち 1 本を用いて, 電波送信所から偏波の直 交した 2 つ無変調光を電波受信所に 送り, 偏波分離後に反射型外部光変調 器で中継放送する 2 波のテレビ受信信 号で, それぞれ強度変調する。 この光 信号を残りの 2 本の光ファイバで送信 所に送り電気信号に変換して, 放送器 に接続するもので, 微弱な受信電波で も充分な変調感度が得られるような共 振回路を組合せた光変調器の構成に特 徵がある．本システムの外観図を図 1 に示す。

\section{（2）中波送信機}

中波送信機については, ディジタル 変調方式がすでに実用化済であるが， モディファイド D 級高効率 PA 用 いた $20 \mathrm{~kW}$ 送信機が開発された ${ }^{6)}$.こ の送信機を含め, 大電力の場合は, 複 数の一定出力の電力増幅器を $\mathrm{ON} /$ OFF する方式が採用されているが，1 $\mathrm{kW}$ 以下の送信機については, この方 式では電力増幅器数, 部品点数が多す ぎて, 低コスト化, 高信頼化を図るこ 


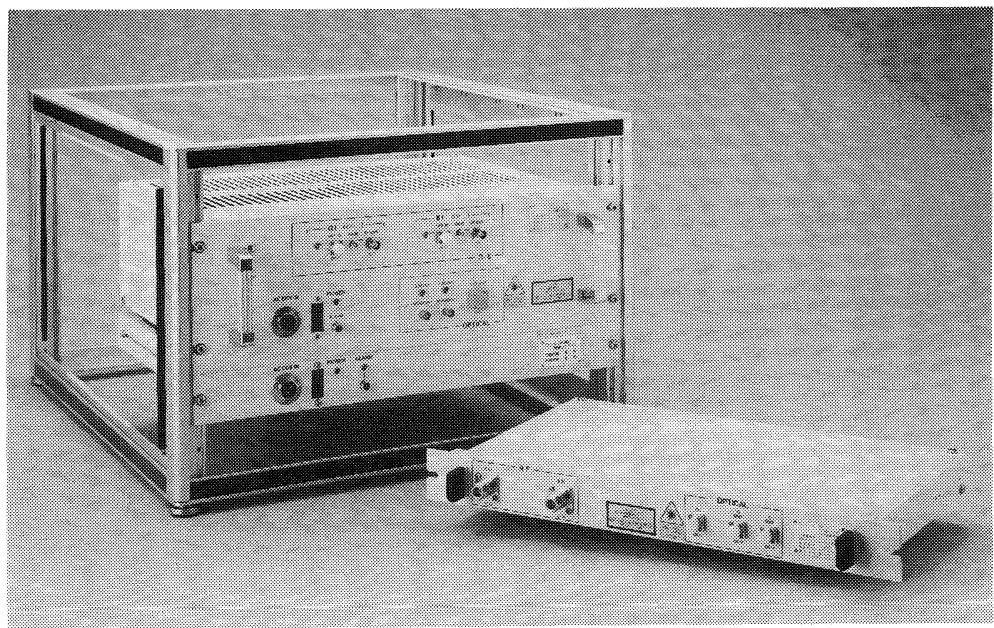

図 1 無給電テレビ電波受信システムの外観

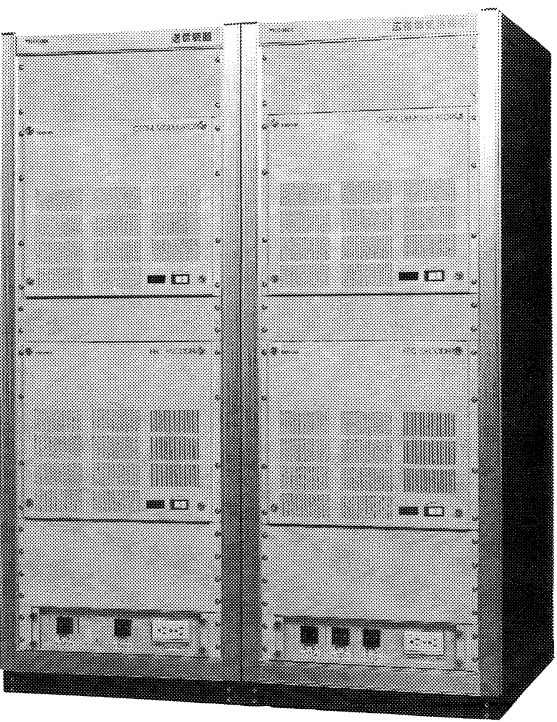

図 2 地上ディジタル放送用変復調装置の外観
とが困難であった。これらの問題点を 解決するため, 電力増幅器の台数が 6 台ですむディジタル位相変調を用いた 方式が考案され, 実用化された ${ }^{7)}$.

送信所が近接する場合, 2 局の相互 変調によるスプリアスの発生を防止す るため, $\mathrm{kW}$ 級の送信所では, その送 信周波数は離しておくのが通例であっ たが, $36 \mathrm{kHz}$ での周波数差による送 信所が実現した ${ }^{8)}$. 周波数資源の有効 利用に貢献したとしている。

（３）電界強度・サービスエリアの 自動計算

従来, $\mathrm{VHF} \cdot \mathrm{UHF}$ 放送の電界強 度地図あるいはサービスエリアの推定 は, 地形図を元に手作業で行われてき たが, 最近のパソコンの高速化と高機 能化を活かして自動計算する手法が開 発された ${ }^{9) 10)}$. 従来の方法による計算 結果あるいは実測結果との比較により 有効性が確認されたとしている。ま た，地上ディジタル放送のサービスエ リア推定にも有効であるとしている。 中波放送についても同様に自動化が行 われている11).

\section{2 地上ディジタル放送(伝送部)}

1997 年 9 月, 電気通信技術審議会 において地上ディジタルテレビジョン 放送伝送方式の暫定方式原案(伝送部 分)が策定された。図 2 は, 暫定方式 原案に基づいて製作された変復調装置 の外観を示す。
この原案策定までには, 多くの研究 が行われてきたが, 本項では, SFN (Single Frequency Network) および 移動受信の伝送に関わる項目, 送信機 に要求される項目について述べる.

\section{(1) $\mathrm{SFN} の$ 検討}

OFDM (Orthogonal Frequency Division Multiplexing)により SFNを 実施する場合, 2 送信局間の周波数差 について検討が行われた ${ }^{12)}$. 一定の BER に対する周波数差を $\mathrm{D} / \mathrm{U}$ 毎にシ ミュレーションしている。移動受信を 想定したDQPSK に比べ固定受信を 想定した 64 QAM では，等しい BER を得るために周波数差を 1 桁以上小さ くする必要がある。これを送信周波数 精度でいうと, 例えば, UHF $62 \mathrm{ch}$ $(770 \mathrm{MHz})$ でキャリヤ間隔 $4 \mathrm{kHz}$ の 場合, DQPSK では $10^{-7}, 64$ QAM で は $10^{-9}$ となる。

放送波中継により SFN を行う場合 には, 中継放送所の送受信空中線間の 回り込みが問題となる. 現状のアナロ グ放送の NTSC 放送波を用いて回り 込みを測定する手法が提案された ${ }^{13)}$. この方法は，GCR 信号を用いて，放 送中に送信アンテナから受信アンテナ に回り込む量(遅延時間および結合量) を測定できる。また，現状の中継局に おける実測も行われており，回り込み は非分離局で約 $80 \mathrm{~dB}$, 分離局で約 $100 \mathrm{~dB}$ 程度であった ${ }^{13) 14)}$.
局間距離約 $8 \mathrm{~km}$ の 2 局から $\mathrm{SFN}$ 送信を行い, OFDM の伝送特性の野

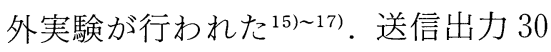
$\mathrm{W}, 19 \mathrm{ch}$, アンテナ高約 $100 \mathrm{~m}$ で, 変調は DQPSK(帯域 $3 \mathrm{MHz}$, キャリ ヤ数 744 , シンボル長 $250 \mu \mathrm{s}$, ガード インターバル $31.25 \mu \mathrm{s})$ と $64 \mathrm{QAM}$ (帯域 $6 \mathrm{MHz}$, キャリヤ数 1414 , シ ンボル長 $250 \mu \mathrm{s}$, ガードインターバ ル $31.25 \mu \mathrm{s})$ である.八木・宇田アン テナを用いた固定受信の場合, ビット 誤り率 $2 \times 10^{-2}$ を得るサービス電界強 度は, DQPSK の場合 $40 \sim 45 \mathrm{~dB}$ $(\mu \mathrm{V} / \mathrm{m})$ であり, $64 \mathrm{QAM}$ の場合 $55 \sim 60 \mathrm{~dB}(\mu \mathrm{V} / \mathrm{m})$ であった.ただし， 受信系の $\mathrm{NF}$ は $4 \mathrm{~dB}$ である.

（2）移動受信の検討

SFN を行った場合の移動受信にお いて，ドップラシフトを受けた遅延波 による BERの劣化について検討さ れ，ドップラシフト量がキャリヤ間隔 の $1 \%$ 以内であれば, BERが $1 \times 10^{-2}$ を満たせることがわかった ${ }^{18)}$.さら に,ドップラシフトの影響の軽減方法 についても検討されている19)20).

（3）送信機の非線形の検討

現行放送用に設計された 2 種の送信 機を用いて, OFDM 送信局に必要な 非直線補償, 電力増幅器のバックオフ

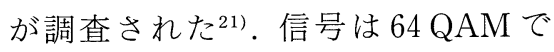
ある. 周波数変換を行うアップコンバ ータのローカル周波数の安定度により 
BER 特性の劣化現象があること, 電 力増幅器の非直線補償は, 現行放送用 補償器により効果のあることが確認さ れた。また，汎用の設計支援ツールを 用いて, OFDM 全系統について非直 線特性をシミュレーションする方法が 考案された ${ }^{22)}$. 実機デー夕とかなりよ く一致した結果が得られている。この 方法は, 歪み補償器の効果や出力 BPF のグループディレイ補償につい てもシミュレーションできる。

(福岡)

\section{3. 素材伝送技術}

\section{1 地上系伝送技術}

地上放送のディジタル化スケジュー ルに合わせ，素材伝送系のディジタル 化も急ピッチに進んでいる，ディジ夕 ル FPUに関してはすでにいくつかの 変調方式が提案されており, 使用目的 に応じた使い分けが検討されている。

$800 \mathrm{MHz}$ 帯のFPUでは, OFDM 変調方式を用いたディジタル FPU の 実験装置が開発された ${ }^{23)}$ 。野外実験を 通じて, 送信電力やアンテナ等の条件 が同じであれば，(1) OFDM-FPUは FM-FPUに比べて伝送距離が長いこ と, (2)ガード等を通過した際にもディ ジタル映像は全く乱れず, 移動伝送に よるマルチパスフェージングに対して も強い特性を有することが示された。 さらに実用化に向けて, OFDM パラ メータが検討された ${ }^{24)}$ 。試作実験装置 による室内実験および野外伝送実験を 通して, ガードインターバル長は約 2 $\mu \mathrm{s}$ ，キャリア間隔は $53 \mathrm{kHz}$ 以下とい った実用化に向けたパラメー夕条件が 示された. 昨年, 電波産業会(ARIB) において規格化された $800 \mathrm{MHz}$ 帯 OFDM 方式FPUは, これまでのア ナログ FPUでは困難であった中継シ ステムの実現が可能であるため，今 後, 小型・軽量および省力化が進め ば，近いうちに番組中継における移動 伝送の主力になることが大きく期待さ れている25).

マイクロ波帯の FPUでは, ディジ タル伝送の一方式として, 多值ディジ タル方式によるディジタル FPUが開 発された ${ }^{26)}$. 室内実験および野外伝送
実験を通じて, 信号帯域幅を 7.5 $\mathrm{MHz}$, 最大周波数偏移を $4 \mathrm{MHzp}-\mathrm{p}$ とすることで, (1) FPU1 チャンネル に割り当てられている $17 \mathrm{MHz}$ の占 有周波数帯域幅を満足し, 隣接チャン ネルのアナログ波への干渉も現行アナ ログ FM と同程度であること, (2)長 距離伝送においても $45 \mathrm{Mb} / \mathrm{s}$ のビッ トレートが実現可能であること, (3)マ ルチパスによる影響も, NTSCの通 常番組に使用している伝搬条件を満足 すれば, 等化器による補正により伝送 可能であることが示されている.

多值ディジタル FM 方式は, 現行 NTSC 用アナログ FPUに多值 ASK アダプタを付加することによってディ ジタル伝送モデムを構成できる。この ため, 現行設備との共用化ができ，ま たアナログ FM 方式との混在運用が 可能であり, 今後予想されるアナログ 方式からディジタル方式への過度期に おいて，ほかの変調方式にないメリッ トがある。この多值ディジタル FM 方式は 1997 年 3 月にARIBにおいて 規格化され，8值ディジタル FM ハイ ビジョンFPUがすでに実用となって おり, ハイビジョン番組の生中継や素 材伝送に活用されている27).

マイクロ波帯のディジタル FPU の 一方式として QAM 方式が検討され た。基礎データの収集, 現行 FM 方 式FPU 運用実態の調査, 耐エコー (マルチパス)特性の評価実験，フィー ルドにおけるエコー特性の調査, およ びエコーの遅延時間に関する検討を行 うことにより, $7 \mathrm{GHz}$ 帯ディジタル FPUの耐ガウス雑音およびエコー特 性に要求される性能が明らかにされ た.さらに, その要求される性能に対 して必要となる波形等化用基準信号の 検討を行い, (1) 256〜512 シンボル以 上連続した基準信号を用いる必要があ ること, (2)基準信号を使った判定帰還 型等化器を用いることで DU 比 $0 \mathrm{~dB}$ 下においても波形等化を行えることが 示され, 多值 QAM 方式のディジ夕 ル FPUに要求される性能を満足する ことが確認されている28).

さらに, マイクロ波帯のディジタル FPUの一方式として, $800 \mathrm{MHz}$ 帯の
ディジタル FPU と同様の OFDM 方 式を使用した，16 DAPSK-OFDM 変 調方式によるハイビジョンディジタル 信号伝送に関する検討が行われてい る ${ }^{29)}$.

ミリ波帯の素材伝送では, $42 \mathrm{GHz}$ 帯ディジタルFPUがARIBにて 1997 年 3 月に標準規格化されており, アナログ FM 方式を利用した $42 \mathrm{GHz}$ 帯ハイビジョンワイヤレスカメラ ${ }^{30)}$, およびディジタル変調方式 (QPSK 変 調方式）を利用し $140 \mathrm{Mb} / \mathrm{s}$ の伝送ビ ットレートを実現する $42 \mathrm{GHz}$ 帯ハイ ビジョンディジタル FPU が開発され た ${ }^{31)}$.八イビジョンディジタル FPU では，ミリ波帯は降雨減衰の影響を強 く受けるが, 誤り訂正符号としてリー ドソロモン符号と畳込み符号を組合せ ること，また低雑音特性を有しかつ受 信電界の大きな変動に応答する受信機 を開発することにより，高品質なハイ ビジョン映像を $25 \mathrm{~km}$ 以上伝送する ことが可能となっている.

そのほかとして, ディジタル信号処 理技術を採用して空間伝送マージンを 大幅に改善することにより，4 km で 双方向運用が可能な光 FPU が開発さ れている32).

\section{2 衛星系伝送技術}

衛星を利用した素材伝送では, SNGがその代表である.MPEG-2 方 式(SP@ML)に準拠した映像信号の 高能率符号化と, リードソロモン $(204,188)$ 符号および曽込み符号 (符号 化率 $2 / 3 ， 3 / 4$ ) とを組合せた強力な誤 り訂正方式による QPSK，さらに QPSKより伝送速度を高めた 8 PSK を利用した伝送装置を採用した完全デ イジタル化 SNG が実用化されてい る.インタフェースもディジタルイン タフェースが装備され, 伝送带域, 画 質，回線状態および伝送信号等，運用 における様々な条件に対応するために 全部で 6 つの伝送モードを備えてい $ろ^{33)}$.

また，映像信号の圧縮方式に MPEG-2のMP@MLを採用し, 変 調方式として TCM-8 PSK (Trellis Coded Modulation-8 Phase Shift Keying)を採用したディジタル SNG 
装置も開発されている ${ }^{34)}$.

さらに, MOK-QPSK (Modified Offset Keyed-Quarternary Phase Shift Keying)がアナログ FM 用固体 化電力増幅器でもその飽和領域まで良 好に使用できることを確認し， MOK-QPSKを採用した実運用可能 な全固体化ポータブル SNG システム が提案されている35)

SNG 用の変調方式では, $\mathrm{MOK}^{-}$ QPSK 変調方式を 8 相 PSK 変調方式 に適応したDL(Double Layered)MOK 変調方式により, 伝送ビットレ ートを 1.5 倍にすることが提案されて いる ${ }^{36)}$.

移動体でのディジタル SNG も開発 されており, 追尾方式としてモノパル ス方式を採用し，GPS と光ジャイロ 等による粗調整と衛星から受信された パイロット信号による高精度の追尾と を複合した追尾装置により，ハイビジ ヨンのディジタル移動伝送を可能にし ている37)38).

(佐藤)

\section{4. アンテナ・電波伝搬}

\section{1 アンテナ}

古くから使われているテレビ受信用 の八木・宇田アンテナについても改良 が続けられている。例えば, アンテナ 素子が欠落した場合の特性変化に関す

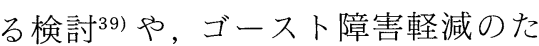
めの簡単な給電構造を有する円偏波八 木・宇田アンテナ40)等の開発が行わ れている。また，広帯域特性を有する テレビ受信用ポリループアンテナにつ いて，地道な検討が続けられてい $3^{41)}$.

一方, 近年に打ける携帯電話や PHS 等の急速な普及, さらには移動 体向けのマルチメディアサービスに対 応して, 新しい移動体通信用アンテナ に関する研究が盛んに行われている。 例えば，線状アンテナを用いたダイバ ーシチアンテナ ${ }^{42)}$, 簡易な追尾機構を もつ衛星通信用プリントアンテナ ${ }^{43)}$, スパイラル状の線状導体をリング状に した小型アンテナ ${ }^{44)}$, 腕時計のバンド に内蔵する小型スロットアンテナ45) などが報告されている。

その他，偏波面調整による混信除去
を目的とした FPU 用アンテナ ${ }^{46)}$, マ イクロ波無線電力伝送に用いる受信ア ンテナ ${ }^{47)}$ 等に関する実用的な検討も 行われている。

\section{2 電波伝搬・電磁環境}

地上ディジタルテレビ放送 (DTTB: Digital Terrestrial Television Broadcasting)では, 移動受信 を含めたシステムの検討が進められて いる. その基本的な一検討として，現 行の地上テレビ放送波を移動受信した ときの受信電界強度分布特性が報告さ れている ${ }^{48)}$.また，課題のひとつであ るドップラシフトの軽減に関しては, 移動受信環境の伝送路特性を解析し, その情報をもとにドップラシフトを抑 圧する等化手法が提案されている ${ }^{49)}$.

無線 LAN あるいは移動通信におい て，建物の壁における電磁波の反射あ るいは散乱を無視することができな い.このような問題を時間領域におけ る数值シミュレーションにより解析 し，種々の特性を明らかにしようとす る試みがなされている ${ }^{50151)}$ 。また，地 上放送波が弱電界となっている地域に おいて，上空の航空機散乱による受信 電界変動が報告されている ${ }^{52)}$.

近年，いわゆる「カーナビ」 ${ }^{53)}$ と呼 ばれる測位システムが一般に広く用い られるようになって来た。これは, 複 数の衛星からの電波を同時に受信する GPS (Global Positioning System) を利用した便利なシステムである。し かし, 最大 $100 \mathrm{~m}$ 程度の誤差が存在 する。これを減らすために, DGPS (Differential GPS) が開発された。 その測定精度をさらに向上させるため の種々の検討も行われている ${ }^{54)}$.

携帯電話等のように身体の極めて近 くで使用する無線機器の増加に伴い, 従来の電波防護指針に関する見直しが 必要となり，1997 年 4 月に電気通信 技術審議会答申55) が出された。本答 申では，新しい電波防護指針およびそ の適用のために必要な測定法, さらに は人体への影響に関する研究項目等に ついてまとめられている。

ELF (Extremely Low Frequency) 電界や定常強磁場の生体影響を定量的 に評価するための基礎的検討も精力的
に行われている ${ }^{5657)}$.また，人体と電 磁界との相互影響を実験的に検討する ための種々のファントムが開発されて いる ${ }^{58) 59)}$.

\section{3 電磁界解析}

従来，八木・宇田アンテナ等の線状 アンテナの解析には, 周波数領域にお ける代表的な数值解法であるモーメン 卜法などの方法が用いられてきた。し かし, 例えば多層構造のマイクロスト リップアンテナ60) などのように複雑 な構造を有する場合の解析には，時間 領域における数值解法のひとつである FDTD(Finite Difference Time Domain)法がよく用いられる。

近年におけるコンピュー夕性能の急 速な向上に伴い，電磁界問題やアンテ ナの解析・設計等に計算機シミュレー 夕61) 63) が多用されるようになって来 た。主な解析手法としては，前述のモ ーメント法, FDTD 法,さらには有 限要素法など, 幾つかの種類がある. 計算機シミュレータの利用は効率的で はあるが，その適用範囲等には充分注 意する必要がある。

（伊藤）

\section{5. ケーブルテレビ伝送技術}

\section{1 通信サービスとの融合}

ここ数年, 社会的必要性からは情報 化社会の進展に伴う通信網の容量不足 から，社会環境的には通信・放送の相 互乗り入れを目指した規制緩和から， 技術的にはディジタル技術の発達か ら，放送サービス (CATVサービス) と通信サービスを同一のネットワーク を用いて提供しようとする, 通信・放 送融合の動きが盛んになってきてい $3^{64)}$.

通信・放送融合には 2 つの流れがあ る。ひとつは通信ネットワークをベー スにCATVサービスを融合しようと する流れであり，1997 年 7 月に横浜 市戸塚区に商用導入された NTT の推 進しているFTTH(Fiber To The Home)がその代表例である。これは 光ファイバネットワークによる WDM(Wavelength Division Multiplexing) 技術を用いた通信・放送の融 合であり，各々のサービスは各々の波 長で独立して提供される。ちなみに， 
$1.3 \mu \mathrm{m}$ が通信サービスに, $1.55 \mu \mathrm{m}$ が放送サービスに割り当てられてい る。また，放送は不特定多数へのサー ビスという特徴に着目し, 光増幅器を 用い, 信号を増幅/分配している.

もうひとつは, CATVネットワー クをベースに通信サービスを融合しよ うとする流れである。CATV は家庭 にまで広带域伝送路を廉価に提供でき る手段であり, 高速大容量通信に利用 できる可能性がある。そのため，各所 で，あらゆる通信サービスを提供しよ うとする試み(通称マルチメディア実 験)がなされている．以下にそれを紹 介する。

1994 年 3 月に関東エリアの主だっ た CATV 事業者を中心とした「次世 代ネットワーク研究会」が設立され, 既存の CATV 施設を利用して，1996 年にかけて通信サービス実験が行われ た ${ }^{65)}$. 内容は, CATV 施設を PHS 基 地局までの伝送路として利用すること の技術的検証, CATV 施設を利用し た電話実験，インターネット接続実験 である.CATV 特有の上り流合雑音 の影響も少なく, 高速通信の実現と常 時接続の可能性については評価が高か った。

一方, 関西エリアでは, 関西の CATV 事業者, マルチメディア関係 企業により「関西マルチメディアサー ビス研究会」が設立され，CATV局 を広域的に連係し, 同様の各種通信サ ービスのフィールド実験が 1996 年 10 月から 1 年間行われた ${ }^{66)}$.また, 郵政 省に打いても, 通信・放送機構 (TAO) が設立され, 実験が行われて いる67)68).

このような実験と並行して, 電話や インターネット接続の商用サービスが 始まっている。特に米国に抢いては, 現在約 11 万世帯がインターネットサ ービスを受けており，2002 年には 300 万世帯以上に達すると予想されてい $3^{69)}$.

CATVネットワークで通信サービ スが可能となった背景には, CATV ネットワークが簡素化できる光通信技 術の進展, すなわち HFC (Hybrid Fiber Coax)化が挙げられるが, ここ
数年に焦点をしぼれば，以下に述べる ようにディジタル信号伝送技術の発達 が注目される。

\section{2 ディジタル伝送技術}

FTTH 型の通信・放送融合に関し ては, 通信信号と放送信号が異なった 波長で伝送されるが, CATV 型の通 信・放送融合に関しては, 通信信号と 放送信号が同一周波数軸上に多重され るため, 特別の工夫が必要である。こ のように, ディジタル信号を, AM$\mathrm{VSB}$ 変調された放送信号と周波数多 重して伝送することを可能とするため に, 現在は $64 \mathrm{QAM}$ 変調方式が採用 されている。

しかし，多重による互いの信号品質 の劣化が新たな問題となって浮上して くる、ひとつは, 放送信号である AM-VSB 信号と通信信号である 64 QAM 信号のレベル設定である. 特 に，互いに隣接した場合，さらにその 放送信号にスクランブルが施されてい る場合には注意を要する。この検討 が，電気通信技術審議会のケーブルテ レビ協議会のディジタル伝送技術専門 部会において, 1995 年 3 月〜1997 年 2 月にかけて, 実験室内だけでなく, 商用サービス中の伝送路を用いて行わ れ70)71)，64 QAM 信号に対する伝送路 性能のガイドラインが示された。な お, スクランブル時, 市販のホーム夕 ーミナルによっては, 帯域内妨害レベ ル值が異なり, ビット詋り率が劣化す る場合も見られており，64 QAM 信 号の帯域内スペクトラムに対する監視 の必要性も確認された。

もうひとつは, 6. に述べる, 光伝 送した場合に生じるクリッピングノイ ズの影響である。伝送実験 ${ }^{72)}$, 理論検 討 ${ }^{73)}$ が行われ, 現在のところ, 伝送 信号の変調度を最適レベルに調整する ことにより対処している。

\section{3 伝送装置}

このように, 技術課題は克服された ものの, 実用化のためには, 低価格機 器の商用化が重要となる.

FTTH 型の通信・放送融合に関し ては, 各家庭に広帯域の放送信号受信 端末が必要となるため, この低コスト 化が重要である ${ }^{74)}$. 通信は通常の電話
設備を用いて行われる。

CATV 型の通信・放送融合に関し ては，逆に，伝送された通信信号をパ ソコンや電話に取り込める信号形態に 変換するモデムと呼ばれる装置が必要 となる．このモデムの統一調達仕様 が，オペレータ主導で 1996 年 3 月 16 日に確定し, 近く, ITU-T 標準とな る見通しである ${ }^{75)}$. それに伴い, 各社 から製品が発表され, CATV 型の通 信・放送融合が現実のものとなってき た。

（村上）

\section{6. 光伝送技術}

\section{1 放送素材系光伝送技術}

放送素材信号のディジタル化に伴 い, 光波長多重を用いたテレビ信号の 局内伝送システムが開発され, フジテ レビジョン新社屋に導入された ${ }^{76)}$ 。こ のシステムは $15 \mathrm{ch}$ のTSCディジ タルコンポジット信号を時分割多重し た信号で光強度変調し，これらを 16 波長多重して分配された 2 系統の伝送 信号から受信端で光スイッチと光フィ ルタで希望の光信号を選択するもの で, 1997 年 3 月より本格運用が開始 された. 波長多重方式は大容量である 他に, ハイビジョンなど多種のフォー マットに対応可能である等の利点があ り，NHKや関西テレビ等にも導入さ れている。現在, ARIB で波長間隔や 光送受信器に関する技術的条件につい てガイドラインがまとめられている.

将来の局内光伝送の多チャンネル化 を目指して, コヒーレント光伝送の周 波数選択性を活かした光 PSK の受信 実験が報告されている77)。この実験で は非圧縮ハイビジョン信号で BPSK 変調した光波を隣接に近い $4.5 \mathrm{GHz}$ 間隔で配列できること, QPSK 変調 による 2 チャンネル伝送の実現性が示 された。

局内伝送以外の屋外中継においても 多数の映像, 音声, デー夕を一括し, 自由にやりとりできる必要性が高まっ た。ここでは屋外中継用に開発された 波長多重ディジタル光伝送装置を 2 つ 紹介する。

そのひとつは, 送信カードあたり映 像 $1 \mathrm{ch}$ と音声 $8 \mathrm{ch}$, タリ $-8 \mathrm{ch}$ を 2 


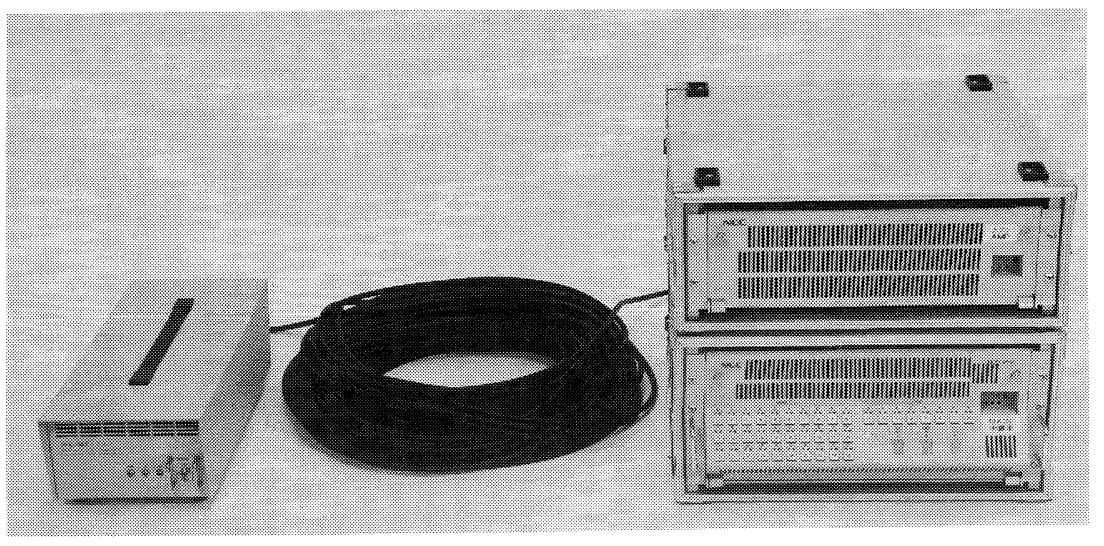

図 3 光伝送装置の外観

波長多重により伝送できるコンパクト な装置で，日本テレビで開発され た ${ }^{78)}$. D 1, D 2,420 P の 3 種類のデ イジタル映像信号に対応できる他に, 6 心の光ファイバケーブルに接続する 送信, 受信カードを入れ替えることで 双方向伝送もできる特徴がある。この 装置はゴルフ中継で威力を発揮した。

もうひとつは, 非圧縮八イビジョン 信号を波長間隔 $0.8 \mathrm{~nm}$ で最大 $32 \mathrm{ch}$ （光 32 波）伝送可能な光伝送装置で NHK で開発された ${ }^{79)}$ 。この装置では 各光源を温度環境の厳しい屋外に置く かわりに屋内に集中配置して送信地点 に分配し, 無変調光を送信地点で変調 することにより光波長の温度ドリフト を低減できるよう工夫されている，外 観を図 3 に示す。

\section{2 放送分配光伝送技術}

ケーブルテレビの分野では，幹線系 に光ファイバ，分配系に同軸ケーブル を用いた HFC システムが大規模な施
設で導入されている。ディジタル放送 波を再送信した場合に, 幹線系伝送用 光源の電気光变換の非直線性に起因し て発生するクリッピング歪みがディジ タル信号の受信に及ぼす妨害について の検討が，64 QAM 信号や OFDM 信 号について行われた。 その結果, 従来 正規分布と考えられていた相互変調歪 みとは乘離したクリッピング歪みの性 質が明らかにされた。

また，ケーブルテレビのサービスエ リアの拡大を目的として, 従来の光強 度変調では $C I N$ が劣化しやすい $\mathrm{VSB} \cdot \mathrm{AM}$ 信号について周波数多重 信号で光一括 $\mathrm{FM}$ 変調を行い, 光へ テロダインにより広带域な電気の FM 信号としてから強度変調して伝送する 方式の研究開発が行われた。

一方，基地局と移動体間での通信用 に，低損失な光ファイバと狭い範囲の 移動体通信に適したミリ波带電波の特 徵を活かした，マイクロ波フォトニク
ス分野の研究が進められた．従来の電 気回路によるディジタル BFN (Beam Forming Network) よりも高速な空間 並列光信号処理を行う光 $\mathrm{BFN}$ を用い たアンテナの提案のほかに, $60 \mathrm{GHz}$ におけるミリ波の光ダウンリンクの実 験が報告されている ${ }^{80)}$ 。この実験は $60 \mathrm{GHz}$ 帯で周波数多重した 2 波の $156 \mathrm{Mb} / \mathrm{s}$ の DPSK 変調信号で電界吸 収型光変調器を用いて強度変調して光 伝送するものである。この実験では, 光ファイバの分散によって信号が劣化 しないように送信側で強度変調の片方 の光側波帯を除去することと, 60 $\mathrm{GHz}$ という高い周波数でも深い光変 調度が得られるような光変調器の整合 回路という 2 つ工夫がなされてい る.

（前田）

\section{7.むすび}

来るべき 21 世紀においては,さら に高度な情報化社会を迎えることは必 須であり，そのためにディジタル伝送 技術や移動体送受信技術などの無線・ 光伝送技術は, ますますその重要性を 増すことになると思われる。一方で は，例えば通信打よび放送サービスの 融合などに見られるような, 社会的問 題や人体に及ぼす電磁波影響の問題な ども今まで以上に考慮する必要が生じ てくると思われる.

無線・光伝送技術に携わる技術者あ るいは研究者は, これらのことを念頭 に置いて高度情報化社会の更なる発展 に寄与することが望まれる。（伊藤）

\section{文献}

1）滝岡ほか: “自動補償機能を備えたディジタル TVエキサイター”,テレ ビ年次大, 15-1 (1996)

2）宮下ほか：“テレビ送信機監視システム”, テレビ年次大, 15-4 (1996)

3）長尾活か：“新型放送機制御板の開発”, 映情学年次大, 26-4 (1997)

4) 長尾ほか: “新型データロガー装置”, テレビ年次大, 15-5 (1996)

5) 藤尾ほか: “光変調器を用いた無給電テレビ電波受信システムの実用 化”, 映情学技報, ROFT 97-56 (1997)

6）村山ほか：“ディジタル振幅変調方式を採用した高効率 $20 \mathrm{~kW}$ 中波送 信機の開発”, 映情学年次大, 26-1（1997）

7) 生岩ほか: “ディジタル位相シフトを利用した新型 AM 送信機”, テレ ビ誌, 50, 7 (1996)

8）北島ほか：“周波数的, 空間的に近接する中波ラジオ送信所の実現”,テ レビ年次大, 15-9（1996）

9）田中ほか：“電界強度地図自動作成プログラム Ele-MAP の開発”, 映情 学技報, ROFT 97-89 (1997)

10）乗松ほか: “テレビジョン放送サービスエリアの自動計算”, 映情学技報, BFO 97-75 (1997)

11）乗松：“中波電波伝搬の自動計算法”, テレビ学技報, BFO 96-82・(1996)
12）岡野ほか：“SFNによる送信局間の許容周波数偏差の検討”, テレビ年 次大, 10-5（1996）

13）今村ほか：“中継放送所送受回り込みの測定法について一放送波中継 SFN の基礎検討”, 映情学技報, ROFT 98-18（1998）

14）田中ほか：“テレビ放送波中継に扔ける同一周波数送受信空中線間結合 量測定一SFN の実現性”, 映情学技報, ROFT 97-40（1997）

15）中原ほか：“SFN 野外基礎実験”, テレビ学技報, ROFT 96-78（1996）

16）中原ほか：“OFDM を用いた SFN 野外伝送実験”, 映情学技報, BFO 97-33 (1997)

17）高田ほか：“OFDM野外伝送実験一DQPSK-OFDM と64 QAMOFDM の固定受信”, 映情学技報, BCS 97-49 (1997)

18）中村ほか：“OFDMによる地上ディジタル放送ートップラーシフトに よる誤り率の低下”, 映情学技報, ROFT 97-34（1997）

19）岡田核か：“OFDMにおけるドップラーシフトの影響の軽減に関する 一考察”, 映情学技報, BFO 97-35（1997）

20）太田ほか：“OFDM 移動受信に拄けるキャリア間干渉軽減の検討”, 映 情学技報, ROFT 97-95（1997）

21）永塚ほか：“現行方式用放送機を用いた OFDM 送信局の構築”, 映情学 
技報, ROFT 97-62（1997）

22）北沢ほか：“OFDM シミュレーション”, 映情学技報, ROFT 97-86 (1997)

23）森山ほか：“OFDM ディジタル FPU の概要”，放送技術，pp. 135-140 (July 1997)

24）森山ほか; “DQPSK-OFDM 変調方式によるUHF 帯 FPU の移動伝送 特性”, 映情学誌, 51, 9, pp. 1542-1549 (1997)

25）滝沢ほか：“800 MHz 帯 OFDM 方式FPU”，放送技術，pp. 97-100 (Mar. 1998)

26）寺田ほか: “多值ディジタル FM 方式によるディジタル FPU 装置の開 発”, 映情学誌, 51, 9, pp. 1533-1541（1997）

27）寺田ほか：“多值ディジタル FM 方式を用いた C/D バンド FPU”, 放送 技術, pp. 75-80 (Feb. 1998)

28）浜住ほか：“7 GHz 帯ディジタル FPUに望まれる性能と QAM 方式 FPU の波形等化方式の検討”, 映情学誌, 51, 9, pp. 1550-1559（1997）

29）森山ほか：“16 DAPSK-OFDM 変調方式を用いたハイビジョンディジ タル信号伝送に関する検討”, 映情学技報, ROFT 97-60（1997）

30）矢島ほか：“42 GHz 带ハイビジョンワイヤレスカメラの開発”, 映情学 年次大 $14-5$ (1997)

31）寺田ほか：“42 GHz 帯ハイビジョンディジタル FPU”, 放送技術, pp 92-96 (Mar. 1998)

32）上村ほか: “小型ディジタル光FPUの開発”, テレビ年次大, 18-4 (1996)

33）杉原浪か：“SNG システム完全ディジタル化”，放送技術，pp. 98-102 (Feb. 1997)

34）寺田ほか：“ディジタル素材伝送”，映情学誌，51，9， pp. 1350 1355 (1997)

35）斎藤ほか：“全固体化ポータブル SNG”,テレビ年次大，18-7（1996）

36）大塚ほか：“SNG用新型ディジタル変調方式”,テレビ年次大, 18 6 (1996)

37）今井ほか：“移動中継「悠久の長江，三峡」”, 映情学技報, ROFT 9719 (1997)

38）水野ほか：“CS 伝送装置”, 映情学年次大, 26-6（1997）

39）住広ほか：“VHF・TV 受信用八木・宇田アンテナの素子欠落による特 性について”, テレビ学技報, ROFT 96-55 (1996)

40）小代ほか：“1 点開放ループを給電素子とした円偏波八木・宇田アレイ アンテナ”, 映情学誌, 51, 1, pp. 121-128（1997）

41）山口：“反射板付き $4 \mathrm{~L}$ ポリループアンテナの指向特性”, 映情学年次大 27-3 (1997)

42）井上ほか: “変形伝送線路型アンテナによるダイバーシチアンテナの研 究”, 映情学技報, ROFT 97-2（1997）

43）坂口ほか：“移動体衛星通信用ビーム切替型円偏波プリントアンテナの 構成”, 映情学技報, ROFT 97-52 (1997)

44）根日屋ほか：“小形スパイラルリングアンテナ”, 映情学技報, ROFT 9757 (1997)

45）岡野ほか：“腕時計型携帯無線機用アンテナの開発”, 映情学技報, ROFT 97-94 (1997)

46）牧野ほか：“可変偏波受信アンテナ装置”, 映情学技報, ROFT 97-55 (1997)

47）山田ほか：“高調波の再放射を抑圧するスリット入り円形マイクロスト リップパッチアンテナに関する考察”, 映情学技報, ROFT 97-68（1997）

48）平井ほか：“移動体に抢ける受信電界強度分布特性の検討”, 映情学技報, ROFT 97-58 (1997)

49）太田ほか：“地上ディジタル放送の移動受信”, 映情学技報, ROFT 97-65 (1997)

50）高橋ほか：“コンクリート壁における電磁波の反射・透過の検討”, 映情 学技報, ROFT 97-88（1997）

51）内田ほか：“壁の山凸による電磁波の散乱”，映情学技報, ROFT 98 8 (1998)
52）永洞ほか：“航空機散乱波による受信電界変動について”，映情学技報, ROFT 98-28 (1998)

53）松田：“カーナビゲーションシステム”，テレビ誌，50，6，pp. 678-685 (June 1996)

54）末松ほか：“GPS 衛星の配置が測位に及ぼす影響について”，映情学技 報, ROFT 98-7 (1998)

55）電気通信技術審議会答申：諮問第 89 号“電波利用における人体防護の 在り方”(Apr. 1997)

56）坂本ほか：“強電界の生体作用機序に関する基礎的検討（その 3)”, テレ ビ学技報, ROFT 96-91（1996）

57）中田ほか：“定常強磁場の生体への影響”, 映情学技報, ROFT 97-83 (1997)

58）三好ほか・“カーボンを用いたシールド材および人体のドライファント ムモデルの研究”, 映情学技報, ROFT 97-25 (1997)

59）浜田ほか：“マイクロ波帯における人体モデルに適したファントムの開 発”, 映情学技報, ROFT 97-76（1997）

60）西山ほか：“無給電素子を装荷した高利得 MSAの FDTD 法による解 析”, 映情学技報, ROFT 98-14（1998）

61）田原ほか：“線状アンテナ数値計算ソフトウエアの比較検討（第 2 報）”, 映情学技報, ROFT 97-12（1997）

62）パネル討論：“マイクロ波・ミリ波技術におけるシミュレータの役割”, $\mathrm{PC}-2$, 平 9 信学総全大 (1997)

63）チュートリアル講演：“アンテナ設計から見た電磁界シミュレータの使 い方と評価”, TB-1, 平 10 信学総全大 (1998)

64）中川：“通信放送融合技術から見たCATV”, 映情学年次大, S 3-4 (1997)

65）銭村：“ケーブルテレビ施設を利用した通信サービス実験”，映情学年次 大, S 3-2 (1997)

66）土森：“ケーブルテレビによる広域マルチメディアサービス実験”, 映情 学年次大, S 3-3 (1997)

67）中村ほか：“広域 CATV 網を使った通信・放送サービスの研究”, 映情 学冬季大, 4-2 (1996)

68）鬼形ほか：“CATV 網を利用したディジタル NVOD システム”, 映情学 冬季大, 4-3 (1996)

69）“ADSL と競うCATVインタネット”，日経コミュニケーション 1998.1 .5 , p. 72 (1998)

70）秋山ほか：“64 QAM 信号の同軸伝送における妨害特性の一検討”，テレ ビ学技報, ROFT 96-80（1996）

71）野田ほか：“ディジタル有線テレビジョン放送方式の伝送実験と伝送路 所要性能の検討”, 映情学誌, 22, 7, pp. 31-36 (1998)

72）田中ほか: “アナログスクランブル信号と $64 \mathrm{QAM}$ 信号の隣接伝送時 における干渉妨害の実験と評価一各種実用機器での実験と評価—その 1”, テレビ学技報, ROFT 96-64（1996）

73）城杉ほか：“光伝送路のクリッピング歪による64 QAM 信号伝送特性 の一検討”, テレビ学技報, ROFT 96-81 (1996)

74）松本ほか：“加入者映像分配システム用宅内設置型 V-ONU の開発”, 信 学技報, OCS 97-15（1997）

75）原島編：小特集 変換期を迎えた CATV，映情学誌，51，11，pp. 17961825 (1997)

76）若月ほか: “光波長多重によるテレビジョン信号の局内信号伝送ネット ワークシステム”, 映情学技報, BCS 98-28 (1998)

77）前田ほか：“位相ダイバーシティ方式 DQPSK コヒーレント復調実験”, 映情学技報, ROFT 98-31（1998）

78）山岸ほか: “マルチフォーマット対応デジタル光多重伝送装置”, 映情学 技報, ROFT 97-54（1997）

79）遠藤ほか：“カメラ用光ケーブルを用いた波長多重伝送”，映情学技報, ROFT 97-93 (1997)

80）久利ほか：“光外部変調器による $60 \mathrm{GHz}$ ミリ波・光ダウンリンク伝送 実験”, 映情学技報, ROFT 98-35（1998） 